\title{
The Real Effect of Banking Crises*
}

\author{
by Giovanni Dell'Ariccia, Enrica Detragiache, and Raghuram Rajan
}

October 2004

\begin{abstract}
Banking crises are usually followed by a decline in credit and growth. Is this because crises tend to take place during economic downturns, or do banking sector problems have independent negative effects on the economy? To answer this question we examine industrial sectors with differing needs for financing. If banking crises have an exogenous detrimental effect on real activity, then sectors more dependent on external finance should perform relatively worse during banking crises. The evidence in this paper supports this view. In addition, differential effects are stronger in developing countries, in countries with less access to foreign finance, and where banking crises are more severe. We examine a number of government interventions during crises, and find that blanket guarantees and regulatory forbearance work best in limiting the effect of banking crises on real activity.
\end{abstract}

* We wish to thank Eisuke Okada for outstanding research assistance. This paper should not be reported as representing the views of the IMF. The views expressed are those of the author and do not necessarily reflect the views of the IMF or IMF policy. 


\section{Introduction}

Banks are thought to be central to business activity. Therefore, when they experience financial distress, governments usually come to the rescue, offering emergency liquidity and various forms of bailout programs. The case for generous bank support, however, is murky for a number of reasons. First, we have the standard identification problem: if bank distress and economic distress occur at the same time, how can we tell the direction of causality? Second, if bank distress does in fact impair economic activity, under what circumstances is this likely to be most harmful? Third, while interventions may save banks, they may not necessarily prevent the distressed banks from affecting economic activity. So do any interventions prevent banks from impairing economic activity, and if so, which ones are they? This paper focuses on these three questions. Of course, from the perspective of policy, there is a fourth question: how do the costs of intervention weigh up against the benefits? We can shed only limited light on this last issue

Empirical studies show that credit to the private sector and aggregate output do in fact decelerate during banking crises (see, for example, Kaminsky and Reinhart, 1999, Eichengreen and Rose, 1998, Demirgüç-Kunt et al., forthcoming). However, this is not necessarily evidence that banking problems contribute to the decline in output: first, the same exogenous adverse shocks that trigger banking problems may also cause a decline in aggregate demand, leading firms to cut investment and working capital and, ultimately, demand for bank credit. These same shocks may also cause a temporary increase in uncertainty, leading firms to delay investment and borrowing decisions. In addition, adverse shocks might hurt borrower balance sheets and exacerbate the effects of asymmetric information and limited contractibility, prompting banks -- even healthy ones -- to curtail lending to riskier borrowers ("flight to quality") or raise lending spreads. To summarize, output and bank credit are likely to decelerate around banking crises even in the absence of a feedback effect from bank illiquidity and insolvency to credit availability. ${ }^{1}$ To identify the real effects of banking crises it is necessary to sort out this joint endogeneity problem.

Problems of joint endogeneity are familiar in studies of whether finance matters to the real economy. They are central to the literature on financial development and growth (Levine, forthcoming) and to the work on whether financial market imperfections worsen economic downturns (the so called "credit channel" literature). To test whether banking crises have real effects, we adopt the "difference-in-difference" approach used by Rajan and Zingales (1998)

\footnotetext{
${ }^{1}$ There are also measurement issues. Specifically, changes in the aggregate stock of real credit to the private sector are not a good measure of the flow of credit available to the economy, especially around banking crises. The stock may fall because a jump in inflation erodes the value of nominal contracts, or because restructuring operation transfer nonperforming loans to agencies outside the banking system. On the other hand, a devaluation increases the domestic currency value of foreign-currency denominated (Demirgüç-Kunt, et al., forthcoming).
} 
to study the effects of finance on growth. ${ }^{2}$ Our premise is that, if industries more dependent on external finance are hurt more severely after a banking crisis, then it is likely that banking crises have an independent negative effect on real economic activity. Using panel data from 41 countries from 1980 to 2000 , we test whether more financially dependent industries experienced slower growth in banking crisis periods, after controlling for firm-year, countryyear, and industry-country fixed effects. This profusion of dummy variables controls for all possible time specific, country specific, and industry specific shocks that may affect firm performance, thereby avoiding the usual difficulties of choosing an appropriate set of control variables.

Note that we focus on a particular view of why banks affect economic activity - the fact that they are critical to the flow of credit, that is, the lending channel view (see, for example, Kashyap and Stein (1997) or Bernanke and Gertler (1995) for excellent overviews). So we are really testing a joint hypothesis, that banks matter, and they matter because they are critical to the flow of credit. Our test has little discriminatory power if banks matter because, for example, they are critical to mediating transactions. ${ }^{3}$

The results are supportive of the joint hypothesis that banking crises have real effects, and at least part of this effect is through the lending channel. More financially dependent sectors perform significantly worse during banking crises, and the magnitude of the effect is nontrivial: more financially dependent sectors (in the $4^{\text {th }}$ quartile of the dependence distribution) lose about 1 percentage point of growth in each crisis year compared to less financially dependent sectors (in the $1^{\text {st }}$ quartile of the dependence distribution). Of course, not all doubts about causality are laid to rest by this methodology, and we conduct a number of additional tests to verify the case.

In particular, one criticism of our testing strategy is that because of balance sheet effects or other financial market imperfections, externally dependent sectors may grow more slowly during any economic downturn, whether a banking crisis or not (Braun and Larraín, 2003). A related concern is that the differential effect might be driven by balance sheet effects following currency crises (which often accompany banking crises). This may happen if more externally dependent sectors tend to have more foreign currency debt. When we allow for separate differential effects during recessions or currency crises, however, the differential effect during banking crises remains significant, suggesting that we are not simply picking up balance sheet effects.

\footnotetext{
${ }^{2}$ The "difference-in-difference" methodology has also been used in a variety of related problems (see, for example, Cetorelli and Gambera, 2001, Beck, 2003, and Bonaccorsi di Patti and Dell'Ariccia, 2004).

${ }^{3}$ Suppose, however, banks expand transactions media by offering lines of credit to bank dependent industries. Then our methodology will pick up the direct effect of lower credit to bank dependent industries, but not the indirect effect of lower effective money supply which would affect all industries and not necessarily the differential.
} 
We also address the issue of the residual endogeneity of the banking crisis variable. If bank dependent sectors are relatively more represented in bank portfolios, asymmetric sectoral shocks affecting these sectors might cause both the banking crisis and the relative underperformance of these sectors. However, we find that more external dependent industrial sectors perform poorly during banking crises even in countries/crises where they represent a smaller share of bank portfolios. This suggests that our correlations are not driven only by asymmetric sectoral shocks.

The second question is to examine where the differential effect is stronger. On the one hand, this gives us a sense of where intervention may be more critical, on the other, if the differential effect is stronger where the theory plausibly suggests the costs of banking crises are likely to be larger, the differential effect itself gains credibility as a measure of the impact of the crisis.

We find the differential effects to be stronger in developing countries, in countries where the private sector has less access to foreign finance, and where the crises were more severe (in a way we will make more precise). These results make intuitive sense: externally dependent sector should suffer less from a banking crisis if they can tap domestic bond or stock markets (as in developed countries) or foreign capital markets. Also, the more severe the disruption in the banking sector, the stronger should be the differential effect.

We turn next to the third question. Using the differential as a measure of the severity of the impact on bank activity, we ask what interventions mitigate this impact. Of course, our data are a sample of crises episodes that are selected to exceed a threshold of severity. We will therefore not pick up interventions that ward off a banking crisis entirely. Nevertheless, this is an interesting question for policy makers - in the face of a crisis, what actually mitigates the impact of the crisis on a channel through which banks affect the real economy?

With the caveat that we have a small sample (that we are trying to expand), we find that both blanket guarantees and measures of regulatory forbearance tend to reduce the differential the most, while other common interventions have little effect. This makes sense: if banks are special, keeping them alive is essential for credit to flow to financially dependent industries. The finding is not without content though. Banks that are kept alive might focus on squeezing borrowers in order to regain liquidity. That they do not seem to do so when given maneuvering room is interesting.

Of course, policy makers are particularly interested in whether the benefits of an intervention outweigh the cost. Since our methodology allows us only to identify the differential effect of an intervention and not the aggregate effect (for instance, if spillovers from the increased growth of financially dependent industries prevents the whole economy from falling into recession) we have little to say here other than interventions that do not affect the differential are unlikely to affect activity through the lending channel, and therefore have to be justified for other reasons. 
The paper is structured as follows: In section II, we explain the empirical methodology and the data, in section III we present the results, in Section IV we have a brief summary of the related literature we conclude in Section V.

\section{The Basic Test}

\section{A. Methodology}

To study whether banking crises have real effects, we ask whether industries more dependent on external finance experience a more severe output loss following a banking crisis. In the benchmark specification, value added growth in industry $j$ at time $t$ in country $i$ is regressed on three sets of fixed effects (industry-year, country-year, and industry-country) and the variable of interest, an interaction term equal to the product of the financial dependence measure for industry $j$ and the banking crisis dummy for year $t$ and country $i$. Following Rajan and Zingales (1998), we also include the lagged share of industry $j$ in country i to account for "convergence" effects, i.e. the tendency of larger industries to experience slower growth. The benchmark regression is:

$y_{i, j, t}=\sum_{i j} \alpha_{i, j} d_{i, j}+\sum_{i, t} \beta_{i, t} d_{i, t}+\sum_{j, t} \gamma_{j, t} d_{j, t}+\delta \operatorname{FINDEP}_{j} \bullet$ BANK_CRISIS $_{i, t}+\varphi S H A R E_{i, j, t-1}+\varepsilon_{i, j, t}$

where the d's denote dummy variables. A negative and significant $\delta$ indicates that banking crises have a relatively worse impact on industries that depend more heavily on external finance. The three sets of fixed effects should control for most shocks affecting firm performance, including -- for instance - the severity of the banking crisis, the level of financial development, global shocks to the industry, aggregate country-specific shocks. This gets around the usual difficulties with omitted variable bias. Indeed, the only shocks not controlled for are those varying simultaneously across countries, industrial sectors, and time. As robustness tests, we also use gross capital formation and number of establishments as the dependent variable instead of value added.

\section{B. Data}

Data on manufacturing value added, investment, and number of establishments are disaggregated at the 3-digit ISIC level and come from the UNIDO, Industrial Statistics, 2003. There are 28 industries at this level of disaggregation, but we have included in the sample observations with as few as 10 sectors to preserve sample size. Value added is deflated using consumer price indexes from the International Financial Statistics. ${ }^{4}$

\footnotetext{
${ }^{4}$ The producer price index would be a more appropriate measure of prices in manufacturing, but it was not available for a number of countries in our sample. In any case, the price index does not affect differences in growth rates across sectors, which is what matters to our tests.
} 
External dependence is defined as the share of capital expenditure not financed with cashflow from operations. The data come from Laeven, et al. (2002), who take them from Compustat, and differ from Rajan and Zingales (1998) in that they include only 3-digit ISIC level sector rather than a mixture of 3 and 4-digit level sectors. ${ }^{5}$ The figures are for U.S. manufacturing firms and reflect industry medians during the 1980s. An important assumption underlying our approach is that external dependence reflects technological characteristics of the industry that are relatively stable across space and time (see Rajan and Zingales (1998) for a discussion of this assumption).

To identify banking crisis inception dates, we rely on information from case studies, including Lindgren et al. (1986) and Caprio and Klingebiel (2003). Following DemirgüçKunt and Detragiache (1998), we consider episodes of bank distress to be systemic crises when at least one of the following conditions holds: there were extensive depositor runs; the government took emergency measures to protect the banking system, such as bank holidays or nationalization; the fiscal cost of the bank rescue was at least 2 percent of GDP; or nonperforming loans reached at least 10 percent of bank assets. We construct a dummy variable that takes the value 1 for the crisis inception year and the two following years, under the hypothesis that the real effect of the crisis dissipate in the medium term. To test robustness, we will also consider narrower and wider crisis windows. A list of banking crises is in the Appendix.

To maximize sample size we use an unbalanced panel in which some country/year/sector observations are missing. Country/years for which less than 10 industrial sectors are available, however, are excluded, to ensure that there is enough information to estimate the differential effect. Constraints on the availability of banking crisis and sectoral value added information leave us with data from 41 countries from 1980 to 2000 for a total of over 16,000 observations, after excluding 2 percent of outliers on either tail of the distribution.

\section{Results}

\section{A. The Benchmark Test}

Estimates from the benchmark regression supports the hypothesis that banking crises have an exogenous effect on the real economy. The coefficient of the interaction term is negative and significant at the 5 percent level, indicating that the growth rate of sectors that rely more

\footnotetext{
${ }^{5}$ See Appendix for more details. Not using 4-digit ISIC sectors helps increasing sample size.

${ }^{7}$ We also change the sample by considering only observations for which data for all the 28 sectors is available. The sample size drops by almost one half. For our baseline specification the coefficient of the interacted term remains negative but is no longer significant. However, when we allow the effect of a crisis to vary between advanced economies and developing countries, the coefficient for the latter is significant at the 10 percent level. These results are not reported.
} 
heavily on external finance is relatively more affected in crisis years compared to sectors that rely less on external finance (Table 1). The economic magnitude of this effect is substantial. On average, in a country experiencing a banking crisis, the difference in value added growth between a sector at the 25 percentile and one at the 75 percentile of the external dependence distribution is 1.1 percentage point per year of crisis. This compares with an average rate of growth of 3.7 per cent in the sample as a whole and 1.7 percent during crisis years.

As sensitivity analysis, we drop from sample the 5-percent tails of the dependent variable distribution. When this is done, the coefficient of the interaction term remains negative and significant. ${ }^{7}$ The results are also robust to correcting standard errors for first-order autocorrelation in the residuals.

Because a priori it is not clear how protracted the real effects of the banking crisis may be, we also estimate regressions using different crisis lengths (from 1 to 5 years) (Table 2). The coefficient of the interaction term remains always negative and is stable in magnitude.

However, it is significant only in the 3-year and 4-year window cases. This suggests that the real effects of the crises peter out after a few years, which is consistent with evidence on the recovery of aggregate output following a banking crisis. ${ }^{8}$

\section{B. Bank Distress or Balance Sheet Effects?}

A concern with our interpretation of the basic regression is that the differential effects we document may reflect balance sheet problems among borrowers rather than their banks. In other words, banking crises often coincide with economic downturns which worsen firm balance sheets. This, in turn, aggravates agency problems and other financial frictions, causing all banks (even healthy ones) to cut back on lending, presumably hurting bankdependent sector disproportionately more. To separate out the effect of financial frictions during recessions from the specific effect of banking crises, we construct a recession dummy variable using GDP data from the World Bank World Development Indicators. Following the peak-to-trough criterion (Braun and Larraín, 2003), we date recessions as follows: first, a trough is identified when GDP falls more than one country-specific standard deviation below its trend level (where trend is computed with a standard Hodrick-Prescott filter). Then, a peak is identified as the last year with positive GDP growth before the trough. The recession dummy variable takes the value of one from the year after the peak to the year of the trough. Using this dummy variable, we estimate the following equation:

${ }^{8}$ Table A3 in the Appendix shows that if crises are set to last four years there is not much difference in average growth rates between crisis and non-crisis periods. In contrast, for shorter durations crisis years have lower growth. Also, in a sample of 36 crises, DemirgüçKunt et al. (forthcoming) find that GDP growth returns to its pre-crisis level in the fourth year of a crisis. 


$$
\begin{aligned}
& y_{i, j, t}=\sum_{i j} \alpha_{i, j} d_{i, j}+\sum_{i, t} \beta_{i, t} d_{i, t}+\sum_{j, t} \gamma_{j, t} d_{j, t}+\delta \text { FINDEP }_{j} \bullet \text { BANK_CRISIS }_{i, t}+\varphi \text { SHARE }_{i, j, t-1}+ \\
& \xi \text { FINDEP }_{j} \bullet \text { RECESSION }_{i, t}+\varepsilon_{i, j, t}
\end{aligned}
$$

If the coefficient $\delta$ capture the differential effect of recessions rather than the banking crises, we would expect it to lose significance in this specification, while $\xi$ would be negative and significant.

As it turns out, there is an overlap between recessions and banking crises, but the overlap is far from perfect: not all recessions coincide with banking crises and not all banking crises occur during economic downturns. When we estimate the regression with both interaction terms, the coefficient of the crisis/dependence interaction term becomes a bit smaller, as one might expect, but remains significant at 5 percent in both benchmark specifications (Table 4). On the other hand, the coefficient of the recession/dependence interaction term has the expected sign (negative), but it is not significant. This finding supports the interpretation that we are picking up not only balance sheet effects, but also disruptions in credit supply due to the banking crisis.

Similar arguments apply to currency crises. These events, especially in countries where the corporate sector has large unhedged foreign currency exposures, may cause large balance sheet effects. If more leveraged firms are also more dependent on external finance, and if large currency depreciations occur in association with banking crises (the "twin crises"), then the differential effect found in the baseline regression may reflect the balance sheet channel rather than distress in the banking sector. To sort out this issue, we rerun the benchmark regressions by adding an interaction term between external dependency and a currency crisis dummy. Following Milesi-Ferretti and Razin (1998), a currency crisis is defined as a year in which the exchange rate satisfies the following three conditions: it depreciates (vis-à-vis the U.S. dollar) at least 25 percent; it depreciates at least twice as fast as in the previous year; and the previous year it depreciated by less than 40 percent. $^{9}$

When currency crises are controlled for, the coefficient of the bank-crisis/dependence interaction term remains negative and significant and of similar magnitude as in the baseline regression (Table 4). The coefficient of the currency-crisis/dependence interaction term has a positive sign, perhaps because more externally dependent sectors tend to be exporting sectors which benefit from a devaluation, but is not significant. This evidence confirms our original interpretation of the results in favor of a genuine differential effect of banking crises and, hence, in support of the notion that bank distress has an exogenous negative effect on economic activity.

\footnotetext{
${ }^{9}$ The latter condition serves to eliminate cases of chronically high inflation countries, in which large rates of depreciation are recorded on a regular basis. This definition corresponds to the second of the four definitions of crisis considered by Milesi-Ferretti and Razin (1998).
} 


\section{Are the Result Driven by Asymmetric Sector-Specific Shocks?}

The methodology employed in this paper greatly reduces the concern for simultaneity biases in the relationship between growth and banking crises. However, the endogeneity of the banking crisis variable might still be an issue if bank dependent sectors are more heavily represented in bank portfolios than less bank dependent sectors. Indeed, if that were the case, asymmetric sectoral shocks concentrated in bank dependent sectors could cause both the banking crisis and relatively poor growth in those sectors

To address these concern, we proceed as follows. Since we do not have data about the sectoral composition of bank portfolios, we assume that, in each country, sectors are represented in bank portfolios roughly proportionately to the product of their share in the country aggregate value added and their external dependency index. For each country and year, we compute the correlation between these estimated shares and the external dependence variable, and split the sample around the cross-country median of the distribution of this correlation. Then, we rerun the baseline specification allowing the coefficient of the interaction term to differ between crises with a high correlation between bank portfolio allocation and external dependence index and crises with a low correlation. If our previous findings were mainly the result of a simultaneity bias, we should find a stronger negative coefficient for the crises with a high correlation, and possibly a non significant coefficient for the others. Instead, the opposite happens (Table 5). The coefficient for the crises where bank dependent sectors represent a relatively smaller portion of bank portfolios is larger than that in our baseline regression and remains significant at the 5 percent level. The coefficient for the other crises, on the other hand, is not significant. This evidence supports our interpretation of our previous results -- banking crises have exogenous real effects.

\section{Where Do Crises Matter Most?}

In our baseline specification all banking crises are treated as having the same differential effect on industries. In practice, this is unlikely to be the case, as different characteristics of the economy may affect the impact of the banking crises, and the crisis itself may be of different nature and magnitude. So the question we now turn to is if bank distress does in fact impair economic activity, under what circumstances is this likely to be most harmful?

Banking crises are likely to have relatively larger real effects in developing countries where bond and equity markets are less developed and where governments may find it more difficult to provide support for troubled banks. For this reason we consider an alternative specification where the coefficient of the interaction term is allowed to differ across advanced and developing countries. The results confirm this conjecture. While the coefficient for advanced countries is not significant, that for developing countries is larger than in the benchmark specification and significant at the 5 percent level. The difference in value added growth between a sector at the $25^{\text {th }}$ percentile and one at the $75^{\text {th }}$ percentile of the external dependence distribution becomes 1.5 percentage points per year of crisis.

In a related vein, the effects of banking crises should differ across countries with different access to foreign finance, under the hypothesis that industries dependent on external finance 
should be more severely affected by banking crises in countries with more limited access to foreign sources of capital.

To proxy for access to alternative sources of finance we use data on disbursement of foreign loans and bonds to the private sector (scaled by the sum of imports and exports). The data come from the Global Development Finance database of the World Bank. Since developed countries are not covered by this database, we arbitrarily set the value for these countries at the largest sample observation, under the assumption that developed country firms have broad access to alternative finance. We then estimate the model using this access parameter to "weigh" the interaction term. Specifically, let $x$ denote the measure of access and $x$ max the maximum value of this variable over the sample. Then the new interaction term is FINDEP $_{\mathrm{j}}$ * BANK_CRISIS ${ }_{\mathrm{it}} *\left[1-\mathrm{x}^{*}\left(0.5 / \mathrm{x}^{\max }\right)\right]$. Thus, for countries with maximum access to external finance the banking crisis dummy takes the value of 0.5 in crisis years, while for countries with no access at all it takes the value of 1 . The estimation results confirm that more externally dependent sectors grow less during crises (Table 5). The coefficient of the new interaction term is larger than in the benchmark specification and it is still significant at the 5 percent confidence level. This suggests that access to foreign finance can help mitigate the real effects of banking crises.

Crises, of course, also differ in severity, and more severe and pervasive crises should have larger real effects than less severe and contained ones. There are several difficulties associated with measuring the severity of a banking crisis, as there is often limited information on the disruption caused by the crisis and available measures may not be fully comparable across countries. Accordingly, rather than attempting to develop an exact measure of the magnitude of each crisis, we just divide the sample between larger and smaller crisis based on three indicators of severity: the fiscal cost of the crisis, the share of non-performing loans on total loans, and the fraction of insolvent bank assets in total bank assets. Because these indicators are not available for all crisis episodes, first we rank the crises according to each of these three variables, and then take the average of the available ranks. This means that some crises are ranked according to all three indicators, and some others according to a subset of them. Episodes are then classified as severe or mild based on the average ranking, and the usual regression is estimated with two separate interaction terms, one for each type of crisis.

The regression results indicate that, while both coefficients are negative, only the interaction term with the more severe crises is significant (Table 5). The magnitude of this coefficient is also larger than in the baseline. This result suggests that banking crises are more likely to have significant real effects in those cases where they are more pervasive and involve the disruption of the orderly functioning of the banking system.

Finally, we have looked thus far at overall value added growth. One might expect the effects of lending to be more direct and pronounced on capital formation. Using investment growth as the dependent variable (dropping 5 percent of outliers, since this variable is noisier) in the baseline regression, the coefficient of the interaction term remains negative and statistically significant (Table 3 ). The differential effect is economically more significant than in the case of value added: an industry at the $25^{\text {th }}$ percentile of the external dependence distribution has 
investment growth 4 percentage points higher than one at the $75^{\text {th }}$ percentile during crisis years.

Another measure that is likely to be sensitive to bank lending is the growth in number of establishments. Furthermore, to the extent that growth in the number of establishments reflects the birth of new firms, this variable has the advantage of being less sensitive to balance sheet effects than value added (see earlier): a new firm is unencumbered by past liabilities, and therefore growth in the number of firms will not be influenced by how the roots of the crisis affect firm balance sheets. The differential effect is again economically more significant than in the case of value added: an industry at the $25^{\text {th }}$ percentile of the external dependence distribution has growth in establishments 0.6 percentage points higher than one at the $75^{\text {th }}$ percentile during crisis years.

In sum then, our methodology suggests that banking crises have the most effect where we would expect from the theory that the lending channel to be most operative. This then suggests that the differential in growth could be taken as a measure of the impact of a crisis on the lending channel. We can then ask what interventions would mitigate the effect on the lending channel the most.

\section{E. Interventions and the Lending Channel}

We compute the effect of a crisis on the bank lending channel as follows:

1. We run the baseline regression with all dummies but no interaction term;

2. For each industry $\mathrm{j}$ and each banking crisis, we average residuals in the 3 banking crisis years. This measures how growth in industry $\mathrm{j}$ differed from the average during the crisis. Call this $\mathrm{u}^{\mathrm{jiBC}}$.

3. For each industry $j$ and country $i$, we average residuals over whole sample period (excluding the crisis years). This measures how growth in industry $\mathrm{j}$ differed from average in the non crisis years. Call this $\mathrm{u}^{\mathrm{jiNBC}}$.

4. For each industry $\mathrm{j}$ and each banking crisis, compute $\mathrm{x}^{\mathrm{jBC}}=\mathrm{u}^{\mathrm{jBC}}-\mathrm{u}^{\mathrm{jNBC}}$. This measures the difference between the residual in years of crisis and in years of no crisis for that industry.

5. Average $\mathrm{x}^{\mathrm{jBC}}$ across industries in the top $\left(\mathrm{a}^{\mathrm{hBC}}\right)$ and bottom quartile $\left(\mathrm{a}^{\mathrm{lBC}}\right)$ of the financial dependence distribution and compute $\mathrm{a}^{\mathrm{lBC}}-\mathrm{a}^{\mathrm{hBC}}$ for each crisis. This is our measure of the effect of the banking crisis on the lending channel.

In Table 7, we list this lending channel effect for the different crises in our sample. The correlation between the lending channel effect and the cost of the crisis in lost GDP is $32 \%$ $(p=0.03)$ suggesting that our measure does capture something meaningful. 
We obtain the list of policy measures undertaken in each crisis from Honohan and Kliengebiel (2003). In this paper, interventions are classified into six categories: blanket depositor protection (including both explicit blanket guarantees to depositors and cases in which depositors are implicitly protected because most of the banking sector is publiclyowned); prolonged and extensive liquidity provision to banks; forbearance of type A (when insolvent/illiquid banks are allowed to continue operating without restriction for at least 12 months); forbearance of type B (either there is forbearance of type A or some regulations, such as loan classification and provisioning, are not enforced); repeated recapitalizations; and, finally, government-sponsored debt relief initiative for corporate or private borrowers. All these variables are captured by simple zero-one dummies.

In Table 8, we plot the correlations between the interventions and the lending channel effect. Interestingly, the correlations are most negative when the authorities decide to offer blanket guarantees and type A forbearance (the most generous type). In a regression with the lending channel measure as a dependent variable and interventions as dependent variables, both these measures appear to significantly reduce the cost of crisis. This result is robust to dropping the other measures from the regressions and controlling for GDP per capita or institutional quality. $^{10}$

While the evidence in this section should be viewed as preliminary, it does suggest that ensuring banks stay open -- through blanket guarantees and a policy of strict forbearance -can limit the impact of the banking crisis on the lending channel. This is not a vacuous result for even if banks were left open, they might attempt to pull back credit in a flight to quality paper. Interestingly, while blanket guarantees also seem correlated with high fiscal costs (see Table 8), strict forbearance is not. If the results in this section hold up, they suggest that a policy of strict forbearance may have substantial beneficial effect with limited costs.

\section{Related Literature}

There is a long literature focusing on the effects of banking crises. For example, Lindgren, Garcia, and Saal (1996) summarizes many early experiences, and concludes that "episodes of fragility in the banking sector have been detrimental to economic growth in the countries concerned." (p. 58). Cross-country studies of banking crises have also shown that output growth and private credit growth drop significantly below normal levels in the years around banking crises, but do not attempt to sort out the direction of causality (Kaminsky and Reinhart, 1999, Eichengreen and Rose, 1998, Demirgüç-Kunt et al., forthcoming).

In their study of the so-called capital crunch in the United States in 1990, Bernanke and Lown (1991) in fact express skepticism that the credit crunch played a major role in the recession of 1990. Instead, they stress demand effects, pointing to the fact that there was little

${ }^{10}$ In the table, we use regulatory quality as the institutional variable, but similar results can be obtained using measures of property rights enforcement, political stability, rule of law, and others. These measures are obtained from Kaufman, Kraay, and Mastruzzi (2003). 
relation between bank capital ratios and employment growth across states, and all types of credit, not just bank credit, fell.

The question of whether banking crises cause a credit crunch was resurrected once more following the Asian crises of 1997-98, and a number of studies attempted to provide answers. Domaç and Ferri (1999) found that small and medium-sized enterprises were hurt disproportionately in Malaysia and Korea, and interpreted this as evidence of a credit crunch as these firms are usually more dependent on bank credit than larger firms. Ghosh and Ghosh (1999) tested an aggregate model of credit demand and supply using Indonesian and Korean data, and found evidence of credit rationing, but only in the first few months of the crisis; afterwards, the decline in credit was explained by lower demand. Using firm level data from Korea, Borensztein and Lee (2002) find that firms belonging to industrial groups (chaebols) lost their preferential access to credit during the banking crisis, although this was not necessarily evidence of a credit crunch. According to Dollar and Hallward-Driemeier (2000), most Thai firms surveyed after the crisis attributed low production levels not to lack of credit, but to poor demand, although many complained about high interest rates. To summarize, studies of the consequences of the Asian crises come to different conclusions as to the relevance of a credit crunch. Also, arguably none of these studies was designed to tackle the joint endogeneity problem head on.

A number of papers have tried to tackle the identification problem in clever ways. Some have examined the issue from the side of banks. Peek and Rosengren (2000) use geographical separation as their means of identifying supply shocks: Japanese banks lost capital as a result of bad loans made in Japan. The authors then show that the withdrawal of these banks from lending to real estate in the United States had a strong dampening effect on US commercial real estate markets. Clearly, it is hard to attribute the fall in real activity to demand side effects. Kashyap and Stein (2000) suggest a lending channel for monetary policy by pointing out that small, less liquid banks seem to curtail credit more in response to tight monetary conditions than large, liquid banks.

Our paper differs from these in that it attempts to identify supply effects by looking to see if borrowing sectors that are more likely to be sensitive to a supply shock are indeed disproportionately affected by it. In this, our paper is closely related to two recent papers:

Braun and Larraín (2003) tests whether industries more dependent on external finance experience a sharper output contraction than other industries during economic downturns, and finds a large positive differential effect. The interpretation is that financial market imperfections make access to credit more difficult during downturns and thus contribute to economic fluctuations. Braun and Larraín also find the differential effect to be larger in countries with poor accounting standards and for industries whose assets are less tangible, supporting the interpretation that financial frictions are at work. These authors do not attempt to distinguish between balance sheet effects, whereby adverse shocks hurt corporate balance sheets making banks more reluctant to lend, and the so-called bank lending channel, whereby 
banks are unwilling to lend because their own financial conditions have deteriorated. Our tests attempt to uncover the presence of a bank lending channel.

In another related study, Laeven et al. (2002) investigate whether banking crises impact sectors dependent on external finance more severely in countries with a less developed financial system. The finding is that the differential effect found by Rajan and Zingales is present in pre-crisis periods, but becomes insignificant (and even changes sign) during crises. The interpretation is that operating in an environment where financial markets are well developed is an advantage for more financially dependent industries in good times, but a disadvantage in times of banking crises. Laeven et al (2002) thus look at the effects of financial development in two distinct regimes. Their focus is not on the effect of the banking crisis within a country, which is our focus.

The problem of separating out the effect of bank distress from other contemporaneous shocks hinders efforts to measure the economic cost of banking crisis and to understand the determinats of these costs. Bordo et al. (2001) argue that financial crises (currency crises, banking crises, or both) have entailed similar-sized output losses in recent years as compared to previous historical periods, although they are more frequent now than during the gold standard and Bretton Woods periods and as frequent as in the interwar years. Hoggarth et al. (2001) claim that, contrary to popular belief, output losses associated with banking crises are not more severe in developing countries than in developed countries.

More recently, Claessens, Klingebiel, and Laeven (2003) study how output losses following banking crises are affected by institutions and by policy interventions. As in our paper, the latter are identified through the Honohan-Klingebiel dataset. The main finding is that generous support to the banking system does not reduce the output cost of banking crises. This conclusion, however, does not take into account that omitted exogenous shocks may cause both a stronger output decline and more generous intervention measures. Using a measure of the cost of crises less marred by this problem, we find that depositor protection and forbearance may indeed be effective to reduce the real cost of crises.

\section{Conclusions}

We have studied the effects of banking crises on growth in industrial sectors and find that in sectors more dependent on external finance value added, capital formation, and the number of establishments grew relatively less than in sectors less dependent on external finance. We interpret this finding as evidence that a lending channel is operative during banking crises. Specifically, while adverse shocks cause both poor economic performance and bank distress, bank distress has an additional, adverse effect on growth, as banks must cut back their lending. As might be expected, the differential effect is stronger in developing countries (where alternatives to bank financing are more limited), in countries with less access to foreign finance, and where bank distress is more severe. In addition, we find that the effect we have measured is not just the reflection of balance sheet effects during recessions or currency crises, but appear to be special to periods in which banks experienced liquidity and solvency problems. 
We also examine a number of government interventions to mitigate the bank lending channel. Though the small sample size makes the results tentative, we find that blanket guarantees and generous regulatory forbearance work best in limiting the effect of banking crises on real activity. 


\section{References}

Bonaccorsi di Patti, Emilia, and Giovanni Dell'Ariccia, 2004, Bank Competition and Firm Creation, Journal of Money, Credit, and Banking, April, Vol. 36/2.

Beck, Thorsten, 2003, Financial Dependence and International Trade, Review of International Economics, 11, 296-316.

Bernanke, Ben S. ; Gertler, Mark, "Inside the Black Box: The Credit Channel of Monetary Policy Transmission,” Journal of Economic Perspectives v9, n4 (Fall 1995): 27-48

Bordo, Michael, Barry Eichengreen, Daniela Klingebiel, and Maria Soledad Martinez-Peria, Is the Crisis Problem Growing More Severe?, Economic Policy, 32, pp. 51-82.

Borensztein, Eduardo, and Jong-Wha Lee, 2002, Financial Crisis and Credit Crunch in Korea: Evidence from Firm-Level Data, Journal of Monetary Economics, 49, 853875.

Braun, Matías, and Borja Larraín, 2003, Finance and the Business Cycle: International, InterIndustry Evidence, mimeo, UCLA and Harvard University.

Calomiris, Charles W., 1997, The Postmodern Bank Safety Net, (AEI Press, Washington, DC).

Caprio, Gerard, and Daniela Klingebiel, 2003, Episodes of Systemic and Borderline Financial Crises mimeo, The World Bank.

Cetorelli, Nicola and Michele Gambera, 2001, Banking Market Structure, Financial Dependence and Growth: International Evidence from Industry Data, Journal of Finance v56, n2, pp. 617-48.

Claessens, Stijn, Daniela Klingebiel, and Luc Laeven, 2003, Resolving Systemic Crises: Policies and Institutions, unpublished manuscript, The World Bank.

Demirgüç-Kunt, Aslı, Enrica Detragiache, 1998, The Determinants of Banking Crises in Developing and Developed Countries, IMF Staff Papers, 45 (1), pp. 81-109.

Demirgüç-Kunt, Asl1, Enrica Detragiache, and Poonam Gupta, forthcoming, Inside the Crisis: An Empirical Analysis of Banking Systems in Distress, Journal of International Economics and Finance.

Dollar, David, and Mary Hallward-Driemeier, 2000, Crisis, Adjustment, and Reform in Thai Industrial Firms, The World Bank Research Observer, 15, 1-22. 
Domaç, Ilker, and Giovanni Ferri, 1999, The Credit Crunch in East Asia: Evidence From Field Findings on Bank Behavior and Policy Issues, mimeo, The World Bank.

Eichengreen, Barry, and Andrew K. Rose, 1998, Staying Afloat When the Wind Shifts: External Factors and Emerging Market Banking Crises, NBER Working Paper No. 6370.

Ghosh, Swati, and Atish Ghosh, 1999, East Asia in the Aftermath: Was There a Crunch?, IMF Working Paper No. 99/38.

Hoggarth, Glenn, Ricardo Reis, and Victoria Saporta, 2001, Costs of Banking System Instability: Some Empirical Evidence, unpublished manuscript, Bank of England.

Honohan, Patrick, and Daniela Klingebiel, 2003, The Fiscal Cost Implications of an Accommodating Approach to Banking Crises, Journal of Banking and Finance, 27, 1539-1560.

Kaminsky, Graciela L., and Carmen Reinhart, 1999, "The Twin Crises: The Causes of Banking and Balance-of-Payments Problems”, American Economic Review, 89 (3), pp. 473-500.

Kashyap, Anil K.; Stein, Jeremy C., "The Role of Banks in Monetary Policy: A Survey with Implications for the European Monetary Union," Federal Reserve Bank of Chicago Economic Perspectives v21, n5 (Sept.-Oct. 1997): 2-18.

Kashyap, Anil K.; Stein, Jeremy C., "What Do a Million Observations on Banks Say about the Transmission of Monetary Policy?", The American Economic Review, Vol. 90, No. 3. (Jun., 2000), pp. 407-428.

Kaufman, Daniel, Aart Kraay, and Massimo Mastruzzi, 2003, Governance Matters III: Governance Indicators for 1996-2002, World Bank Policy Research Working Paper No. 3106.

Laeven, Luc, Daniela Klingebiel, and Randall Krozner, 2002, Financial Crises, Financial Dependence, and Industry Growth, World Bank Research Working Paper No. 2855.

Levine, Ross, forthcoming, Finance and Growth: Theory, Evidence, and Mechanisms, Handbook of Economic Growth.

Lindgren, Carl-Johan,Tomas J.T. Baliño, Charles Enoch, Anne-Marie Gulde, Marc Quintyn, and Leslie Teo, 1999, "Financial Sector Crisis and Restructuring. Lessons from Asia,” IMF Occasional Paper No. 188.

Milesi-Ferretti, Gian Maria, and Assaf Razin, 1998, Current Account Reversals and Currency Crises: Empirical Regularities, IMF Working Paper No. 98/89. 
Peek, J and E. Rosengren, "Collateral Damage: Effects of the Japanese Bank Crisis on Real Activity in the United States", The American Economic Review, Vol. 90, No. 1. (Mar., 2000), pp. 30-45.

Rajan, Raghuram, and Luigi Zingales, 1998, Financial Dependence and Growth, American Economic Review, 88 (3), 393-410. 
Table 1. Differential Effect of Banking Crises on Value Added Growth

\begin{tabular}{lccc}
\hline & Benchmark & Outliers 5 percent & Newey-West \\
Crisis3*Dependence & -2.74 & -2.01 & -2.74 \\
& {$[2.19]^{* *}$} & {$[2.07]^{* *}$} & {$[2.30]^{* *}$} \\
Lagged Share & -2.44 & -1.69 & -2.44 \\
& {$[13.99]^{* * *}$} & {$[12.24]^{* * *}$} & {$[13.32]^{* * *}$} \\
Constant & 8.46 & 3.33 & 8.46 \\
& {$[1.23]$} & {$[0.47]$} & {$[1.22]$} \\
Observations & 16227 & 15213 & 16227 \\
R-squared & 0.33 & 0.34 & 0.33 \\
& & & \\
\hline
\end{tabular}

Robust t-statistics in parenthesis. ***,**, and * denote significance levels of 1 percent, 5 percent, and 10 percent respectively. Crisis3 is a dummy variable for the year of banking crisis inception and two following years. Dependence is a parameter measuring an industry's dependence on external finance (Rajan and Zingales, 1998). Lagged share is the share of the sector's value added in total value added lagged by one period. Regressions are estimated with OLS and also include time-country, time industry, and industry-country dummy variables. 
Table 2. Differential Effect of Banking Crises on Value Added Growth: Different Crisis Duration

(1)

$$
-1.36
$$

[0.74]

Crisis2*Dependence

Crisis $3 *$ Dependence

Crisis4*Dependence

Crisis $5 *$ Dependence
(3)

(4)
(5)

\begin{tabular}{|c|c|c|c|c|c|}
\hline Crisis 1 *Dependence & $\begin{array}{l}-1.36 \\
{[0.74]}\end{array}$ & & & & \\
\hline Crisis2*Dependence & & $\begin{array}{l}-1.95 \\
{[1.42]}\end{array}$ & & & \\
\hline Crisis $3 *$ Dependence & & & $\begin{array}{c}-2.74 \\
{[2.19]^{* *}}\end{array}$ & & \\
\hline Crisis4*Dependence & & & & $\begin{array}{l}-1.71 \\
{[1.52]}\end{array}$ & \\
\hline Crisis5*Dependence & & & & & $\begin{array}{l}-1.45 \\
{[1.37]}\end{array}$ \\
\hline Lagged Share & $\begin{array}{c}-2.44 \\
{[13.97]^{* * *}}\end{array}$ & $\begin{array}{c}-2.44 \\
{[13.98]^{* * *}}\end{array}$ & $\begin{array}{c}-2.44 \\
{[13.99]^{* * *}}\end{array}$ & $\begin{array}{c}-2.44 \\
{[13.99]^{* * *}}\end{array}$ & $\begin{array}{c}-2.44 \\
{[13.98]^{* * *}}\end{array}$ \\
\hline Constant & $\begin{array}{c}8.37 \\
{[1.21]}\end{array}$ & $\begin{array}{c}8.40 \\
{[1.22]}\end{array}$ & $\begin{array}{c}8.46 \\
{[1.23]}\end{array}$ & $\begin{array}{c}8.42 \\
{[1.22]}\end{array}$ & $\begin{array}{l}-29.62 \\
{[1.58]}\end{array}$ \\
\hline Observations & 16227 & 16227 & 16227 & 16227 & 16227 \\
\hline R-squared & 0.33 & 0.33 & 0.33 & 0.33 & 0.33 \\
\hline
\end{tabular}

Robust t-statistics in parenthesis. ***,**, and * denote significance levels of 1 percent, 5 percent, and 10 percent respectively. CrisisN (with $\mathrm{N}=1,2,3,4,5$ ) is a dummy variable for the year of banking crisis inception and following N-1 years. Dependence is a parameter measuring an industry's dependence on external finance (Rajan and Zingales, 1998). Lagged share is the share of the sector's value added in total value added lagged by one period. Regressions are estimated with OLS and also include time-country, time industry, and industry-country dummy variables. 
Table 3. Differential Effect of Banking Crises on Value Added Growth: Balance Sheet Effects and Asymmetric Sectoral Shocks

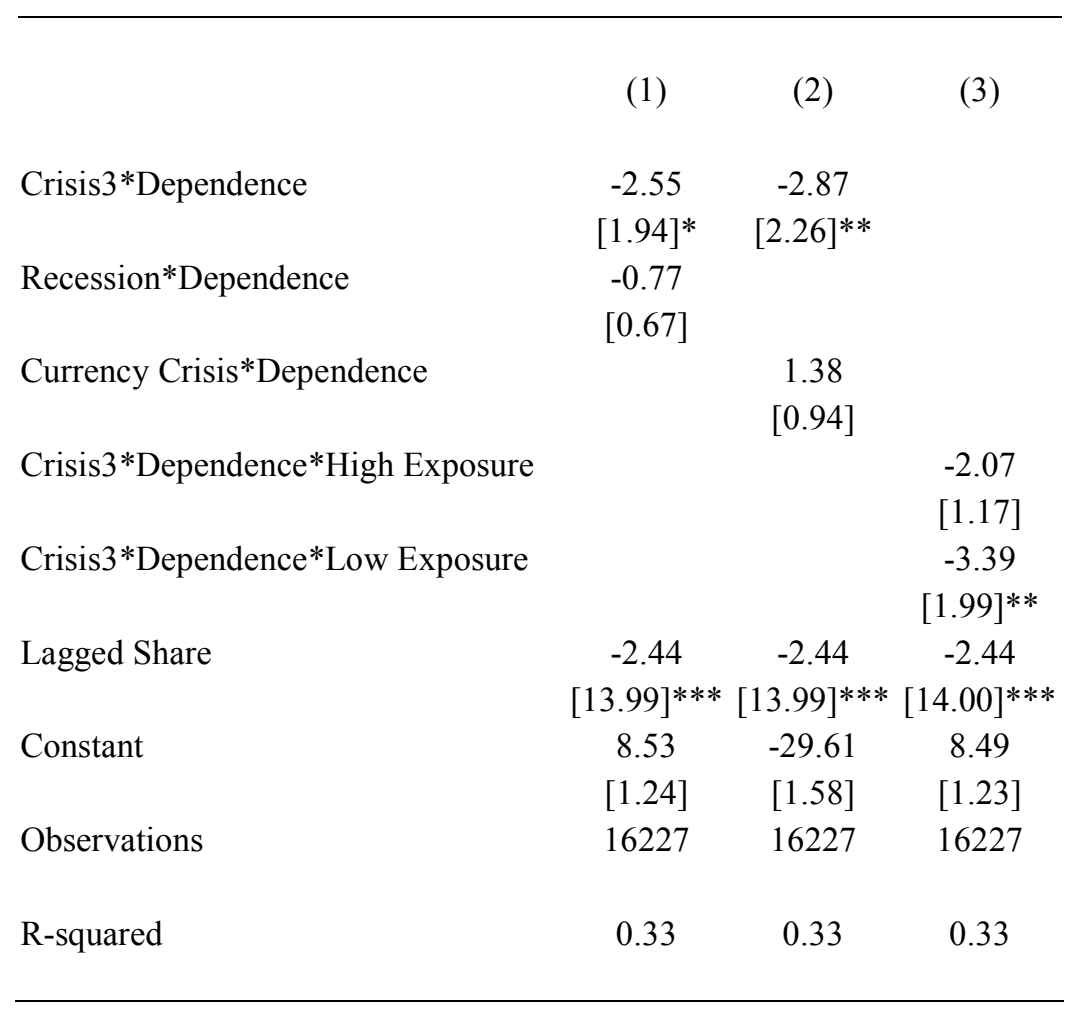

Robust t-statistics are in parenthesis. ***, **, and * denote significance levels of 1 percent, 5 percent, and 10 percent respectively. Crisis 3 is a dummy variable for the year of banking crisis inception and two following years. Dependence is a parameter measuring an industry's dependence on external finance (Rajan and Zingales, 1998). Recession is a dummy for recession years. Currency crisis is a dummy for currency crisis years. High exposure are crisis episodes in which Dependence is highly correlated with a proxy of bank exposure to the sector. Lagged share is the share of the sector's value added in total value added lagged by one period. Regressions are estimated with OLS and also include time-country, time industry, and industry-country dummy variables. 


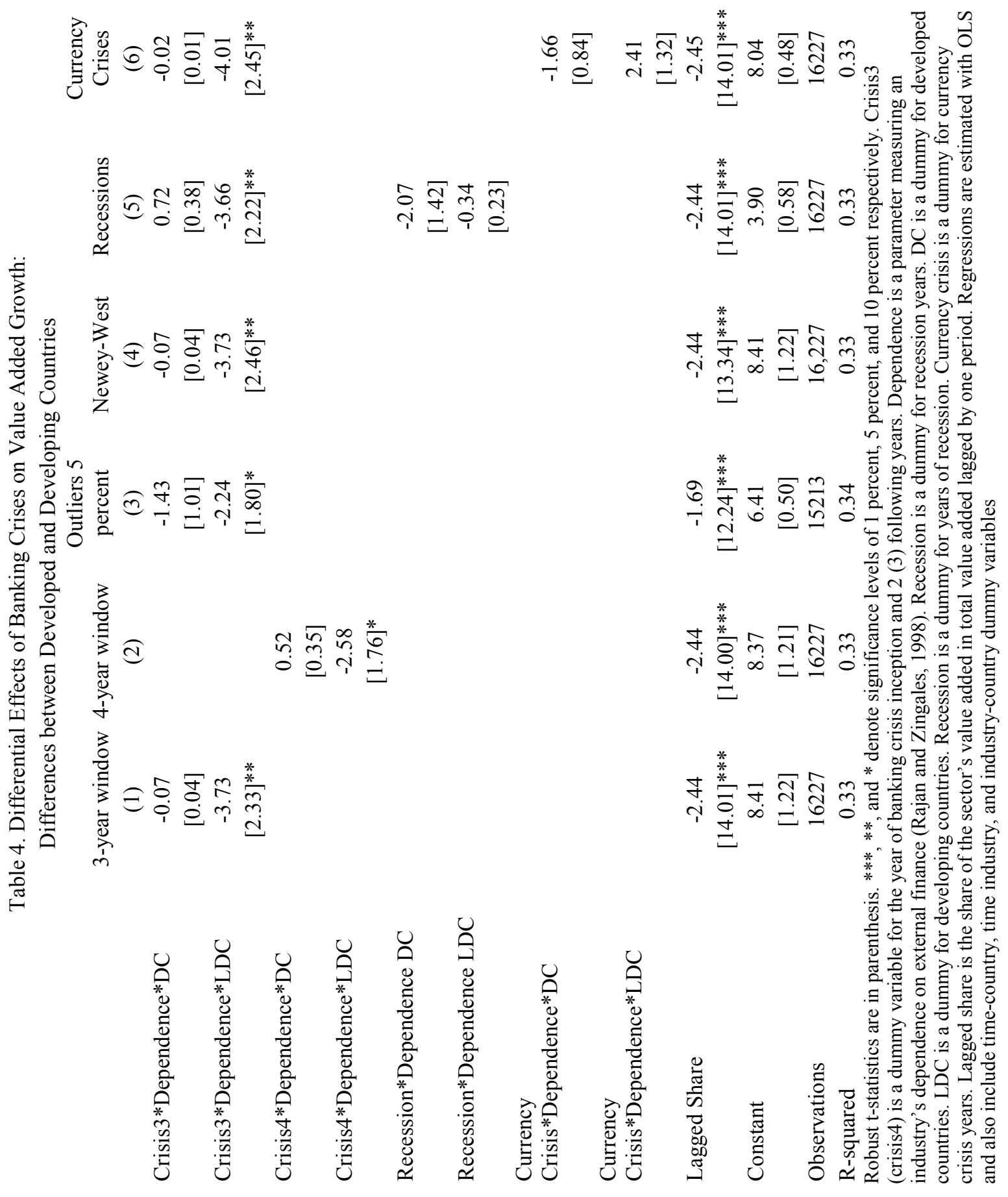


Table 5. Differential Effect of Banking Crises on Value Added: Difference Among Countries and Crises

Dependence*Access*Crisis3

Dependence*More Severe

Dependence*Less Severe

Lagged Share

Constant

Observations

R-squared
(1)

$-3.66$

$[2.37]^{* *}$

$-4.18$

$[2.12]^{* *}$

$-2.51$

[1.22]

$-2.44 \quad-2.43$

$[14.00]^{* * *}[13.89]^{* * *}[12.62]^{* * *}$

$8.49 \quad 3.84 \quad 1.11$

$[1.23] \quad[0.56] \quad[0.09]$

$16227 \quad 15640 \quad 13464$

$0.33 \quad 0.34 \quad 0.34$

Robust t-statistics are in parenthesis. ***, **, and * denote significance levels of 1 percent, 5 percent, and 10 percent respectively. Crisis 3 is a dummy variable for the year of banking crisis inception and two following years. Dependence is a parameter measuring an industry's dependence on external finance (Rajan and Zingales, 1998). Access measures access to foreign finance using external disbursement to the private sector. More (less) severe denotes crises where the banking sector was more (less) severely disrupted. Lagged share is the share of the sector's value added in total value added lagged by one period. Regressions are estimated with OLS and also include time-country, time industry, and industry-country dummy variables. 
Table 6. Differential Effects of Banking Crises on Growth in Capital Formation and the Number of Establishments

\section{Capital formation Number of Establishments}

Crisis $3 *$ Dependence

Crisis $3 *$ Dependence*DC

Crisis $3 *$ Dependence*LDC

Lagged Share

Constant

Observations

R-squared
(1)

$-9.85$

$[2.34]^{* *}$
$-9.32$

[1.56]

$-10.12$

[1.85]*

$-2.21$

$[3.75]^{* * *}$

28.52

[0.76]

9752

0.29
$-2.21$

$[3.75]^{* * *}$

28.51

[0.76]

9752

0.29
(3)

$-1.47$

$[2.18]^{* *}$

(4)

$-0.93$

[0.87]

$-1.71$

[1.95]*

$-0.47 \quad-0.47$

[5.58]

$-7.8$

[5.59]

17.57

[1.04] [1.79]*

$9684 \quad 10402$

$0.42 \quad 0.42$

Robust t-statistics are in parenthesis. $* * *, * *$, and $*$ denote significance levels of 1 percent, 5 percent, and 10 percent respectively. Crisis3 is a dummy variable for the year of banking crisis inception and two following years. Dependence is a parameter measuring an industry's dependence on external finance (Rajan and Zingales, 1998). DC is a dummy for advanced countries, LDC is a dummy for developing countries. Lagged share is the share of the sector's value added in total value added lagged by one period. Regressions are estimated with OLS and also include time-country, time industry, and industry-country dummy variables. 
Table 7. Cost of Crisis from Bank Lending Channel

\begin{tabular}{|c|c|}
\hline Episode & Cost of Crisis \\
\hline Argentina 1989 & -0.7 \\
\hline Argentina 1995 & 3.3 \\
\hline Bolivia 1986 & -3.9 \\
\hline Bolivia 1994 & -16.4 \\
\hline Brazil 1994 & -4.6 \\
\hline Cameroon 1995 & -0.7 \\
\hline CAR 1988 & 13.9 \\
\hline Sri Lanka 1989 & 15.1 \\
\hline Chile 1981 & 19.1 \\
\hline Colombia 1982 & -3.6 \\
\hline Colombia 1999 & 8.1 \\
\hline Costa Rica 1994 & 6.4 \\
\hline Ecuador 1995 & 1.7 \\
\hline Finland 1991 & -4.3 \\
\hline Ghana 1982 & -12.8 \\
\hline India 1991 & -4.6 \\
\hline Indonesia 1992 & 17.0 \\
\hline Israel 1983 & -6.7 \\
\hline Italy 1990 & 0.6 \\
\hline Japan 1992 & 6.9 \\
\hline Jordan 1989 & -9.4 \\
\hline Kenya 1993 & 5.6 \\
\hline Korea 1997 & -4.1 \\
\hline Madagascar 1988 & 5.9 \\
\hline Malaysia 1985 & 3.7 \\
\hline Malaysia 1997 & -5.2 \\
\hline Mexico 1994 & 2.3 \\
\hline Nepal 1988 & 26.6 \\
\hline Nigeria 1991 & 18.6 \\
\hline Norway 1987 & 7.0 \\
\hline Panama 1988 & 11.8 \\
\hline PNG 1989 & 5.1 \\
\hline Peru 1983 & 6.8 \\
\hline Philippines 1981 & 0.1 \\
\hline Portugal 1986 & -11.0 \\
\hline Senegal 1983 & 9.5 \\
\hline South Africa 1985 & 1.1 \\
\hline Swaziland 1995 & -32.9 \\
\hline Sweden 1990 & 5.3 \\
\hline Tunisia 1991 & -5.0 \\
\hline Turkey 1982 & -0.5 \\
\hline Turkey 1991 & -8.6 \\
\hline Turkey 1994 & -6.1 \\
\hline Turkey 2000 & -5.0 \\
\hline Tanzania 1988 & 11.4 \\
\hline USA 1980 & -2.0 \\
\hline Uruguay 1981 & 10.5 \\
\hline Venezuela 1993 & 22.0 \\
\hline
\end{tabular}




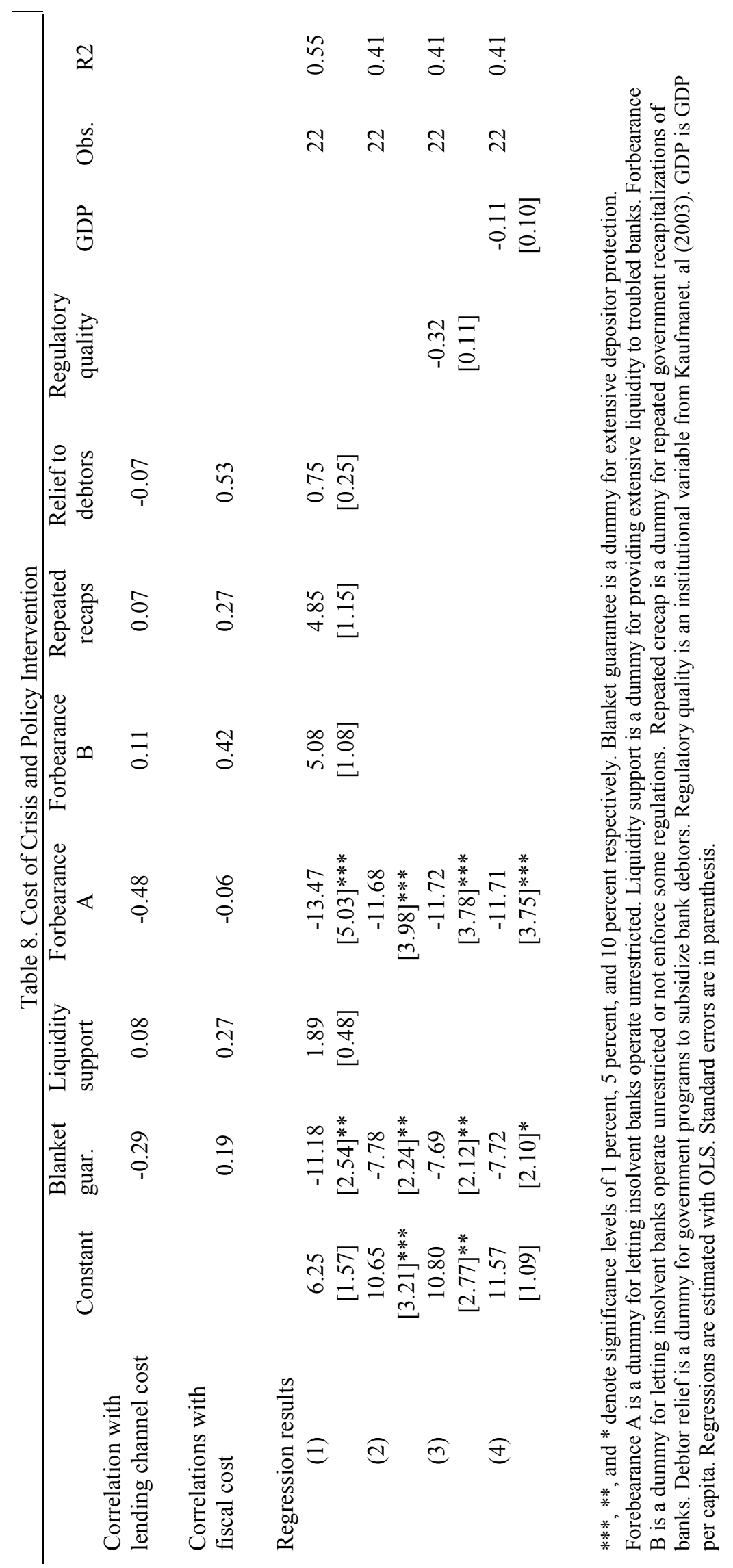




\section{Data Appendix}

Table A1. External Dependence Index

\begin{tabular}{|c|c|}
\hline & $\begin{array}{c}\text { External } \\
\text { Dependence }\end{array}$ \\
\hline Tobacco & -0.45 \\
\hline Pottery & -0.15 \\
\hline Leather & -0.14 \\
\hline Footwear & -0.08 \\
\hline Non ferrous metal & 0.01 \\
\hline Apparel & 0.03 \\
\hline Petroleum refineries & 0.04 \\
\hline Non metal products & 0.06 \\
\hline Beverages & 0.08 \\
\hline Iron and steel & 0.09 \\
\hline Food products & 0.14 \\
\hline Paper and products & 0.17 \\
\hline Textile & 0.19 \\
\hline Printing and publishing & 0.2 \\
\hline Rubber products & 0.23 \\
\hline Furniture & 0.24 \\
\hline Metal products & 0.24 \\
\hline Industrial chemicals & 0.25 \\
\hline Wood products & 0.28 \\
\hline $\begin{array}{l}\text { Petroleum and coal } \\
\text { products }\end{array}$ & 0.33 \\
\hline Transportation equipment & 0.36 \\
\hline Other industries & 0.47 \\
\hline Glass & 0.53 \\
\hline Machinery & 0.6 \\
\hline Other chemicals & 0.75 \\
\hline Electric machinery & 0.95 \\
\hline Professional goods & 0.96 \\
\hline Plastic products & 1.14 \\
\hline
\end{tabular}

Source: Krozner, Leuven, and Klingebiel (2002). 
Table A2. Banking Crises Inception Dates

\begin{tabular}{|c|c|}
\hline Countries & Banking Crisis Inception \\
\hline Argentina & 1989 \\
\hline Argentina & 1995 \\
\hline Bolivia & 1986 \\
\hline Bolivia & 1994 \\
\hline Brazil & 1994 \\
\hline Cameroon & 1995 \\
\hline Central African Republic & 1988 \\
\hline Chile & 1981 \\
\hline Colombia & 1982 \\
\hline Colombia & 1999 \\
\hline Costa Rica & 1994 \\
\hline Ecuador & 1995 \\
\hline Finland & 1991 \\
\hline Ghana & 1982 \\
\hline India & 1991 \\
\hline Indonesia & 1992 \\
\hline Israel & 1983 \\
\hline Italy & 1990 \\
\hline Japan & 1992 \\
\hline Jordan & 1989 \\
\hline Kenya & 1993 \\
\hline Korea & 1997 \\
\hline Madagascar & 1988 \\
\hline Malaysia & 1985 \\
\hline Malaysia & 1997 \\
\hline Mexico & 1994 \\
\hline Nepal & 1988 \\
\hline Nigeria & 1991 \\
\hline Norway & 1987 \\
\hline Panama & 1988 \\
\hline Papua New Guinea & 1989 \\
\hline Peru & 1983 \\
\hline Philippines & 1981 \\
\hline Portugal & 1986 \\
\hline Senegal & 1983 \\
\hline South Africa & 1985 \\
\hline Sri Lanka & 1989 \\
\hline Swaziland & 1995 \\
\hline Sweden & 1990 \\
\hline Tanzania & 1988 \\
\hline Tunisia & 1991 \\
\hline Turkey & 1982 \\
\hline Turkey & 1991 \\
\hline Turkey & 1994 \\
\hline Turkey & 2000 \\
\hline United States & 1980 \\
\hline
\end{tabular}


Uruguay

1981

Venezuela

1993

Total number of crises $=48$ 
Table A3. Average Growth of Real Value Added in Crisis and Non-Crisis Years

$\begin{array}{lcccc}\text { Crisis duration } & \text { Crisis } & \text { No. Obs } & \text { Non-Crisis } & \text { No. Obs } \\ \text { 1-Year Dummy } & 0.10 & 1130 & 4.00 & 15097 \\ \text { 2-Year Dummy } & -0.92 & 2167 & 4.45 & 14060 \\ \text { 3-Year Dummy } & 1.70 & 3059 & 4.20 & 13168 \\ \text { 4-Year Dummy } & 3.33 & 4012 & 3.86 & 12215 \\ \text { 5-Year Dummy } & 3.84 & 4851 & 3.69 & 11376\end{array}$

